\author{
Бучок Ліанна Василівна, \\ здобувач Національної академії керівних \\ кадрів культури і мистецтв, \\ викладач-методист фортепіано та \\ концертмейстер Комунального вищого \\ навчального закладу \\ «Ужгородський коледж культури і мистецтв» \\ Закарпатської обласної ради \\ ORCID 0000-0002-6692-5220 \\ lianna350@ukr.net
}

\title{
ОСОБЛИВОСТІ СТАНОВЛЕННЯ ТА РОЗВИТКУ ЗАКАРПАТСЬКОЇ КОМПОЗИТОРСЬКОЇ ШКОЛИ У ПРИКЛАДАХ ФОРТЕПІАННОЇ ТВОРЧОСТІ др. поЛ. ХХ ст.
}

\begin{abstract}
Мета роботи - визначити особливості характеру стилетворчих ініціатив у фортепіанній творчості закарпатських композиторів др. пол. XX ст. як такого культуротворчого явища, що має стосунок до Інтенціонального періоду історії музики. Методологія дослідження має основою новітні аналітичні підходи до вивчення глибинної структури музичного тексту засобом семантичного та герменевтичного дискур-аналізу, що як аналітична методика сформувався на тлі понятійно-смислової корекції фундаментальних питань сучасного музикознавства та удосконалення його категоріального апарату; у тому числі - категорії «національного», сучасний понятійний вміст якої передбачає передусім алгоритми етнонаціональної ідентифікації у системі «тотожності різних» (світова художня культура). Наукова новизна полягає у виведених на прикладах фортепіанної творчості закарпатських композиторів періоду др. пол. ХХ ст. особливостях становлення та розвитку закарпатської композиторської школи: це інтенції щодо одномоментного поєднання завдань на предмет опанування академічними технологіями музичного мислення та апробації новітніх (інноваційних) принципів стилеутворення. Висновки. 3'ясовано, що становлення і розвиток закарпатської композиторської школи припадає на так званий Інтенціональний період історії музичної культури 3 його екстенсивним характером стилетворчих ініціатив (стилізації, ідеалізації, алюзійний розвиток стилю тощо). Причому, слід очевидних зрушень у стильовій парадигмі щодо національного дискурсу стилеутворення виявляється тісно пов'язаним iз стильовими ремісценціями, оскільки суто національний вектор стилеутворення прагне «дорівнятися» до макроіндивідуаційних процесів резонування у так званій історичній множині стильових систем.
\end{abstract}

Ключові слова: інтенціональний період розвиту музичної творчості, закарпатська композиторська школа, фортепіанна музика.

Бучок Лианна Васильевна, соискатель Наџиональной академии руководящих кадров культурь и искусств, преподаватель-методист фортепиано и конщертмейстер Коммунального высшего учебного заведения «Ужгородский колледж культуры и искусств» Закарпатского областного совета

Особенности становления и развития закарпатской композиторской школы в примерах фортепианного творчества втор. пол. XX в.

Цель работы - определить особенности характера стилеобразующих инициатив в фортепианном творчестве закарпатских композиторов втор. пол. ХХ в. как такого культурообразующего явления, которое имеет отношение к Интенциональному периоду истории музыки. Методология исследования имеет основой новейшие аналитические подходы к изучению глубинной структуры музыкального текста посредством семантического и герменевтического дискур-анализа, что как аналитическая методика сформировался на фоне понятийно-смысловой коррекции фундаментальных вопросов современного музыкознания и усовершенствования его категориального аппарата; в том же числе - категории «национального», современное понятийное содержание которой предусматривает алгоритмы этнонациональной идентификации в системе «тождества разных» (мировая художественна культура). Научная новизна состоит в выявленных на примерах фортепианного творчества закарпатских композиторов периода втор. пол. ХХ в. особенностей становления и развития закарпатской композиторской школы: это интенции касательно одномоментного соединения заданий на предмет овладения академическими технологиями музыкального мышления и апробации новейших (инновационных) принципов стилеобразования. Выводы. Уяснено, что становление и развитие закарпатской композиторской школы приходится на так называемый Интенциональный период истории музыкальной культуры с его экстенсивным характером стилеобразовательных инициатив (стилизации, идеализации, алюзийный способ развития стиля и прочее). Причём, след явных сдвигов в стилевой парадигме касательно национального дискурса стилеобразования оказывается тесно повязанным со стилевыми ремисценциями, поскольку собственно национальный вектор стилеобразования стремится «приравняться» к

( ) Бучок Л. В., 2019 
макроиндивидуализационным процессам резонирования в так называемом историческом множестве стилевых систем.

Ключевые слова: интенциональный период развития музыкального творчества, закарпатская композиторская школа, фортепианная музыка.

Buchok Lianna, a candidate for a degree in art criticism at the Department of Variety Art of the National Academy of Leaders of Culture and Arts of Ukraine, teacher of the piano and concertmaster of the Uzhhorod College of Culture and Arts, Transcarpathia

Formation and development of peculiarities of Transcarpathian school of composition based on examples of piano art of the second half of XX century

The purpose of the article is to determine the peculiarities of the stylistic devices nature in piano art of the Transcarpathian composers of the second half of the XX century as a culturally developing phenomenon related to the intentional period in the history of music. The methodology of the research is based on the latest analytical approaches to the study of the deep structure of the musical text by means of semantic and hermeneutic discourse analysis. As an analytical technique, it has been formed on the background of conceptual and semantic updating of the fundamental issues of the modern music study and the improvement of its categorical apparatus. The modern conceptual content of the category of "national" provides, first of all, algorithms of ethnonational identification in the system of "identity of different" (world art culture). The scientific novelty of the paper is provided in the peculiarities of the formation and development of the Transcarpathian composer's school piano art of the second half of the XX century. It is a means of a simultaneous combination of the tasks for mastering academic technologies of musical thinking and approbation of the latest (innovative) principles of stylization. Conclusions. It has been revealed that the formation and the development of the Transcarpathian composer's school concur on the so-called intentional period of the musical culture history along with its extensive character of style-creating devices (stylization, idealization, allusive style development, etc.). Moreover, the obvious changes in the style paradigm concerning the national discourse of stylistics are closely linked to stylistic remixes, since the purely national style of stylization tends to "matching" the macro individualization resonating processes in the so-called historical set of stylistic systems.

Key words: Intentional period of music development, Transcarpathian school of composition, piano music.

Актуальність теми дослідження. Посилена увага до вивчення саме регіональної специфіки академічної музичної творчості $є$ на сьогодні чи не найбільш пріоритетною цариною української мистецтвознавчої думки, оскільки «у світі немає нічого безетнічного» (вислів Ентоні Д. Сміта). Відтак, прискіпливий аналіз витоків та перспектив структуризації цієї специфіки з огляду на процеси етнонаціональної ідентифікації є адекватним щодо викликів постмодерної фази культуротворення, яка в одиничному мислить духовну цілісність картини світу; зокрема - діагностики ментального роду «рухів» на кшталт виповнювання ментального поля певного культурного простору щоразу новими мислеформами.

Аналіз досліджень і публікацій. У найбільш загальному плані заявлений аналітичний підхід маємо можливість вбачати у розвідках музикознавців української діаспори (наприклад, В. Витвицький [1]), які ще у п. пол. ХX ст. мали основою певні міркування щодо специфіки національного менталітету та характеру стилетворчих процесів у період становлення української професійної композиторської творчості. Поміж тим, безпосередньо історія дослідження професійної музичної творчості композиторів Закарпаття розпочалася із автобіографічних нарисів у жанрі «творчого портрету» - Д. Задора (автор Я. Рак) та І. Мартона (автор Н. Піцур) тощо. Услід за тим осібну сферу інтересу склали також розробки, які присвячувалися «забутим» іменам та маловідомим регіонального значення постатям (автори О. Грін, I. Попова, Т. Росул). I лише віднедавна дослідження сукупного досвіду професійної творчості композиторів Закарпаття сформувався у своєрідну аналітичну традицію (автори Е. Добровольська, О. Короленко, М. Лиховид, В. МадярНовак, О. Маркуш, Л. Микулинець, Л. Мокану, В. Мухіна, К. Оленич, М. Панченко, Л. Уральський, О. Юрош) - але, із перевагою того ж таки автобіографічного та морфологічного підходу. Спостережено, відтак, що на сьогодні практика дослідження фортепіанної творчості композиторів Закарпаття здебільшого акцентує лише регіонально стилістичну «колористику» реального музичного тексту - поза осягненням реальних стилетворчих ініціатив його авторів у дусі реінтерпретаційних (неореставраційних) «рухів» культуротворення Інтенціонального періоду історії музики, що надавало б можливість осягати узагальнення рівня професійних здатностей композиторів закарпатського краю у контексті такої «тотожності різних», як світова музична культура XX ст. - з усією багатоманітністю iii стильових орієнтувань. Крім того, важливо розуміти, що на Закарпатті (як і в Галичині) опанування академічними принципами музичного мислення відбувалося не лише у режимі «синдрому наздоганяння», але й «руху на випередження», що подекуди надавало привід для суджень про «стретний» характер стилетворчого процесу (визначення В. Витвицького $\left[\begin{array}{lllll}1, & 13\end{array}\right]$ - коли спостерігається одномоментне співіснування історично відмінних типів стильових систем. 
Мета дослідження полягає у тому, аби осягнути характер стилетворчих процесів, що його засвідчує фортепіанна творчість закарпатських композиторів періоду др. пол. XX ст.

Виклад основного матеріалу. Як відомо, у новітній музичній творчості вектор стилеутворення iз попереднього динамічного характеру самоздійснення - коли пріоритетною була ямбічна (у широкому сенсі цього слова) напрямна, - доволі різко змінився на екстенсивний (розширювальний) модус із показово розмаїтими художньо-стильовими уподобаннями. Усе це - підстава для пошуку особливих аналітичних алгоритмів на основі онтологічних порівнянь із музичною практикою попередніх мистецьких епох. Бо ж на сьогодні не складає заперечення такий факт, що наявні аналітичні методики, які зросли в лоні класичної наукової картини світу та класичної теорії музики, не $\epsilon$ спроможними пояснювати процесуальний характер новітніх творчих концепцій (про це детально пишуть Н. О. Герасимова-Персидська [2, 32-47], О. П. Опанаюск [7, 271-286], Б. О. Сюта [9, 35-42]). Більше того, ще до недавно абсолютно визнана пріоритетність так званого цілісного аналізу також втрачає свою універсальність й потребує залучення підходів «дискурс-аналізу» - коли позиція 3'ясування певних закономірностей культурного становлення втрачає свій сенс. Причиною тому, власне, є екстензія (розширення, поширення) процесуального становлення та розвитку новітнього музичного мистецтва - засади його інтенціональної зумовленості та специфічної характерності культурних смислів. А отже, лише беручи до уваги суто процесуальний та структуральний аспекти в їхній інтенціональній акцентуації (зосередженості на певних смислах) відкривається шлях до адекватного осягнення творчого задуму в сенсі «функції інтенціонального означення» або, більш загально, «конструктивної функції» (визначення Р. Інгардена [3, 455-456]).

Наприклад, інтегративний характер таких понять, як «інтонаційна модель» (визначення В. Г. Москаленка [6, 50]) та «інтонаційний рельєф тематичного матеріалу» (визначення К. О. Руч'євської $[8,65-67])$ незмінно змушує до зауваги так званих генетичних витоків музичного тематизму та його цілісної герменевтичної реінтерпретації, висуваючи тим самим специфічні аналітичні акценти. Тобто, мова йде про оновлення методологічних параметрів музикознавчої аналітики, а надто - стосовно проективних можливостей розвитку сучасної музичної творчості, коли доводиться апелювати до методу так званого «концепційного аналізу» (визначення А. Демченка) «виявлення образного змісту як базової позиції, на основі чого відбувається індуктивне сходження від специфічно-музичного до більш ширших, культурологічних і соціологічних категорій, а через них - до усвідомлення загальнолюдського змісту, закладеного у творі» $[5,145]$.

Так, регіональну специфіку витоків професійної музичної творчості на Закарпатті визначають суто історичні чинники життєвих форм етнічних громад та ідея етнонаціональної самоідентифікації (фольклористична діяльність, усамостійнення хорової традиції як національно характерної, освітнє спрямування музичної творчості). Причому, поява на цьому тлі саме фортепіанних композицій фактично уперше заявила про суто академічні корені професійної музичної творчості на Закарпатті, $\mathrm{i}$ не тільки: одночасно із цим відбувався історично закономірний процес ії стильової спеціалізації - на зразок історично складеної стильової панорами європейської музики. Але, унікальність самого стилетворчого процесу забезпечував особливий метод творення стилю - заснований на стилізаціях та алюзіях (букв. - натяк; вид непрямого цитування), що уповні відповідає духові модерних (інноваційних) інтенцій культуротворення.

Проте передусім важливим був дидактичний аспект - професійне поповнення педагогічного репертуару в початковій музичній освіті цього багатоетнічного регіону та реально діюча система професійної музичної освіти, до формування якої на Закарпатті першим долучився Зізмунд Лендєл (1892 - 1970): під його орудою упродовж 1920 - 1944 pp. діяла приватна музична школа. 3 віддалі часу слід відзначити, що це був особливий дидактичний матеріал: його стильову основу складали постромантичні стильові дискурси, які грунтуються на мислеформах ідеалізації етнічних фольклорних традицій та прицільного опанування інтенціями щодо професіоналізації академічної музичної творчості. Наприклад, у «Пасторалі» 3. Лендєла - це драматургічно осмислений перебіг композиційної форми за ознаками поемності (ліричні відступи, підтекстові асоціації тощо), який включає також вишукані «маневри» варіантного переінтонування та варіаційної обробки базових інтонем тематичного матеріалу. У числі останніх - епічна модальність наспіву, гнучкий перехід від кантиленності до танцювальності, а також (і це вельми важливо) - техніка тематичної роботи зразка гайднівського та моцартівського симфонізму. Але що характерно: увесь інтонаційний процес огорнутий метафорою рефлексивного споглядання, що «осучаснює» інтонаційно-драматургічну перспективу тематизму цієї п’єси.

Інший приклад - «Маленька фантазія» 3. Лендела на старовинні угорські фантазії: у ній композитор також застосовує, так би мовити, наскрізну траєкторію розгортання «сюжету», але при 
цьому урізноманітнює його притаманними для класицизму раціонально налаштованим оброблянням тематичних осередків - у спосіб тематичної роботи, коли передусім показовими є фактурні та артикуляційні (штрихові та агогічні) зміни. Не менш характеристичною на вираз $є$ також його «Пісня» для фортепіано: дидактично вона спрямована на ментальну характерність закарпатської народної пісні - рефлексивно заангажованої роздумами та вчуваннями. I знову ж таки, як і у попередньо аналізованих п'єсах, композитор вельми скрупульозно покладається саме на драматургічну перспективу: від зачину як задуми (Andante), крізь власне «спів душі» (Andantino) до мислеформи «вдарити лихом об землю» - чардашу.

Натомість у фортепіанній творчості Дезидерія Задора (1912 - 1985) маємо можливість споглядати інтенції щодо неокласичних стильових орієнтувань - коли є алюзія щодо певного історично відомого репрезентанта. У «Скерио», наприклад, це - алюзія на класичні моделі жанрової семантеми скерцо (жарту) в регламенті алгоритмів «емансипованого дисонансу» та атональних співвідношень, а також ексцентричних артикуляційних прийомів у моделі «Sprechstime» як мовленнєво виразного інтонаційного проінтонування музичної лексики. Своєю чергою, «Фуга» Д. Задора має у собі риси суто «бахівської» моделі артикулювання смислів у декламаційній манері та «пісенній» природі контрапунктичних проведень. До-речі, на загал прийнято вважати, що професійна композиторська школа формується відтоді, коли іiї очолює людина, яка здобула професійну музичну освіту саме як композитор. І це попри те, що насправді фактичність появи такої школи є пов'язаною із значно більшою кількістю чинників, хоча серед них й справді чільне місце посідає критерій академічної спеціалізації творчості. На Закарпатті таким очільником й виявився Дезидерій Задор (учень Я. Кржічки, В. Новака, А. Хаби), творчістю якого охоплено чи не найважливіші засади формування композиторської школи: академічна спеціалізація жанрової системи творчості, глибокі інтонаційні корені джерельної бази регіону, гнучка взаємодія стильових систем тощо.

Ще однією знаковою постаттю щодо накопичення педагогічно орієнтованого фортепіанного матеріалу закарпатської композиторської школи є Еміль Кобулей (1929 - 2004) - людина універсальних задатків в плані творення етнографічно орієнтованої музичної свідомості та професійних основ музичної освіченості. Як вихованець видатних музичних теоретиків (А. Котляревський, С. Павлюченко, С. Людкевич), Е. Кобулей зумів на високому професійному рівні відтворити технології стильової спеціалізації фортепіанного репертуару в дусі постромантичних традицій. Так, у «Мініатюрі» - це стилізація патетичного духу шопенівських фортепіанних прелюдій; у «Прелюдi» - мужньо-епічного духу лістівських симфонічних прелюдів, коли «укрупнюється» ліричний суб’єкт та його ментальна своєрідність у значенні «суб'єкта історії». Окрім того, саме у «Прелюді» (звернімо увагу на суто «чоловічу», як і в прелюдах Ф. Ліста, форму артикуляції жанрової форми) Е. Кобулей вдається до атрибутики вільного модуляційного плану поза критеріями тісних функціональних співвідношень у межах основної тональності в ефекті «розширеної діатоніки» зразка $\quad$ С. С. Прокоф'єва та атональних співвідношень зразка глави Нововіденської школи А. Шенберга. Але усі ці стилістичні «блукання» композитор урівноважує медитативними ремісценціями у стилі «чуттєвого» класичного гармонічного виду ладу. Урешті-решт, до дидактичних завдань Е. Кобулей уводить також «випробування» на типову для фольклорної слов'янської лексики ладову перемінність: у п’єсі «Танок Мікі» (Міка - донька композитора) цілеспрямовано зіставляються однойменні мажорно-мінорні осередки та їхні ладові різновиди, що як дієвий прийом на ментальному рівні позначає психотип закарпатців - дуалізм рефлексії та заповзяття.

Своєю чергою, послідовники зачинателів професійної композиторської школи Закарпаття, серед яких чільне місце займає постать Іитвана (Степана) Мартона (1923-1996), дедалі інтенсивніше розвивають вектор стилістичного та суто стильового урізноманітнення педагогічного репертуару піаністів-початківців. Так, у своїй «Елегї̈» для фортепіано композитор віднайшов власні кореляти семантики цієї «романтичної» за естетикою жанрової форми як смутку за втраченим: його осереддям постає інтонема емоційно збурених рефлексій фольклорного походження - патетика інструментальних форм музикування на цимбалах. Однак, у композиції «П'єса» композитор сягає ще більших аналогій із стильовими прикметами вже новітньої форми музичного «звукомислення» творення музичної матерії посередництвом вишуканої «звукової ідеї». Тому у виразовому плані вирішальне значення має момент артикуляції - інтонаційного увиразнення тематичних проведень із гнучкою мінливістю метричних співвідношень та суто штрихових «формулювань» у проведенні певної інтонеми (декламації, урбаністики, загальних форм руху тощо). Усе це, отже, свідчить про інтелектуальну завантаженість тематичного процесування, яке є достойною мислеформою входження у простір вже новітньої музичної свідомості та іiі концептуальних зрізів у дусі 
інноваційних упроваджень щодо способу творення стилю засобом свідомих контамінацій (запозичення, стилізації тощо) в сенсі широко трактованої його «предметності» та смислових полів.

Сенс вище описаних змін щодо принципів стилеутворення подекуди обумовлюється в дусі «фази європеїзації» - феномена, що для української культури в цілому постає осібною у своєму буттєвому статусі 3'явою як змагання «дорівнятися» до здобутків західноєвропейської культури маневром експансії назовні та маніфестуючи лише вибрані цінності [10, 189-191]. Так, стосовно закарпатської композиторської школи історично склалося так, що у фортепіанних композиціях др. пол. XX ст. вистежується фактично одночасне співіснування як мікро- так і макроіндивідуаційних процесів: 3 одного боку, намір етнічної самоідентифікації виявляється як самоціль; 3 іншого інтенсивно залучаються реінтерпретаційні (неореставраційні) «рухи», що відповідають такій глобальній ідеї доби модернізму, як «ідея глобального культурного синтезу» (визначення О. Козаренка $[4,250])$. Наприклад, «Етюд» до мінор Дезидерія Задора (час написання - 1952 рік) репрезентує собою яскраво модерну/сецесійну стильову модель, що грунтується на характерній для постромантизму авторській стилізації певного історично відомого - свідоме уподібнення із кількома ментально відмінними образними системами: шопенівськими драматичними пориваннями, патетикою скрябінських поем, вольовою напругою бетговенського тематизму й навіть звуковою урбаністикою (як у музиці І. Стравинського чи П. Гіндеміта). Але усе це - лише стилістичні атрибути твору. Водночас, власне стильові особливості цього «Етюду» «вимальовуються» у суто концептуальній площині: перелічені асоціації, що їх ідентифікує слух у вимірах стилістичної характерності історично відомих зразків тематизму, є ампліфікованим (з ефектом перебільшення) засобом «повідомлення» про певне «щось». I це «щось» умоглядно складається у духовний образ Людини, яка за своїм внутрішнім складом $є$ амбівалентною: з одного боку - креативність (пафосна віртуозність), драматичне й навіть героїчне поривання та потужна воля; з іншого - спадні емоції упокореного ліризму. Причому, останні - це ключові моменти композиційної форми, драматургічна перспектива якої забезпечується різкими перепадами-зсувами та зміщеннями у значеннях образу (враховуючи навіть фінальну «крапку» твору). А отже, лише драматургічна (смислова) перспектива «Етюду» Д. Задора безпосередньо вказує на ментально характерний образ-концепт у його динамічній структурі - в якості суб'єктивованого інтонаційного образу світу.

Своєю чергою, задля продовження та увиразнення думки щодо ідеалізації саме романтичних традицій у фортепіанній творчості закарпатських композиторів др. пол. ХХ ст. варто звернутися також до Кониерту для фортепіано з оркестром того ж таки Д. Задора (час написання - 1966 рік): у цьому творі композитор максимальною мірою відтворює заангажованість саме построматичними ідеалізаціями. У їх числі - мислеформа «Людина і Природа», архетипи етнічної культури, та головне - суто класичний підхід до структурування концепції, коли гостро актуальним є зіткнення протилежностей (діалектичний тип). Така концепція завжди вимагає особливо динамічного розвитку - як «прагнення до найвищої точки напруження, до крайньої нестійкості - щоб “розв'язатись” у ствердженні, у вольовій перемозі, закріпленій над стійкістю “останньої” крапки: ще і ще раз тоніка всією силою могутнього оркестру. Це - домінування ямбічності в широкому розумінні слова. Сам динамічний процес перебігу має контрастну криву - 3 гострими піками і глибокими спадами. Музичний час яскраво векторний, хоча притому встановлює рівновагу між усіма трьома характеристиками часу (минуле - теперішній час - майбутнє)» $[2,34]$. Цитоване судження Н. О. Герасимової-Персидської, яке дослідниця наводить з метою зіставлення концепцій класичного та $a$ 'класичного мистецтва, якнайкраще (бо з віддалі часу) надає можливість охарактеризувати суть концепції Концерту Д. Задора як такого постромантичного проекту, де містяться також духовноетичні потуги доби постмодерну: власне суть цих потуг - в ідеалізації класичних традицій симфонізму як методу творчого мислення у їхній прозорій розпізнаваності. Однак, у драматургічному плані Концерту Д. Задора репрезентанти ідеалізації (чіткість та ясність композиційного структурування), оскільки є синтезованими 3 лірико-епічним модусом (сполука зіставлення та контрасту), привносять маневр уникання конфліктності та іiі заміщення засобом внесення стороннього смислу: це тотальна ідеалізація та реінтерпретація водночас романтичної модальності захоплення фольклорними витоками та образними асоціаціями «на тему» рідного краю - його пейзажів, символьних образів та сюжетів, - а також включення елементів «гри» стильовими алюзіями.

Водночас, при інтенціях модернізації музичної творчості осібним чином завжди виникає питання щодо іiї зв'язку з академічним (в сенсі класичного) досвідом. I це попри те, що виклики сучасності - це не стільки зречення від традиції, скільки ії продовження у щоразу нових трансформаційних версіях. У цьому сенсі мова йтиме про один із ранніх творів Д. Задора - його 
фортепіанну «Сонату» (час написання - 1960 рік), у якій композитор доволі неординарно втілює ідею сонатності в ролі іiі семантичних основ шляхом іiі реінтерпретації як неореставрації: це неокласичний творчий проект та типово модерністична напрямна «волі до стилю», де семантема «sonare» (букв. «звучання») забезпечується параболічним типом співвідношення сегментів концепції (iз різкими зсувами-зміщеннями у значеннях образу). Провідним засобом «руху» музичної матерії $\epsilon$ лінеарний принцип, що неначе зсередини наснажений ілюстративного значення ефектами фольклорного походження (за М.В.Лисенком - це принцип «національної підсвітки») інструментального типу музикування на цимбалах; але водночас ці «спалахи» експресії виявляють ідентичність декламаційній природі музичного тематизму зразка Нововіденської школи. Водночас автор чітко слідує драматургічній формулі «inito : motus : terminus»: перший драматургічний сегмент - це інтонаційна формула зразка «теми-епіграфу» на яку покладено сенс акустичного коду тематизму, що як «тон-фабула» в інтонемі декламаційного типу запитуванням втілює семантему на зразок риторичного «Cvo wadis?/Куди грядеш?»; другий реалізовано в різнопорядкових модальностях «руху» та «споглядання»; останній переведено у багатозначну смислову атрибуцію «трьох крапок». Зокрема, посередництвом безперервної акустичної присутності певного роду інтервальних співвідношень 3 їх специфічним ладовим контекстом стабільно утримується «подієвий» контраст супроти остинатної форми «руху» прелюдійного зразка: це потужний драматургічний рух «уступами» в тирадній (від tirare - тягти) манері довготривалими емоційно наснаженими в піднесеному тоні «фазами», які буквально втручаються у щойно налагоджену модель руху. Результатом усьому цьому $\epsilon$ індивідуально-стильова, свідомо укладена парадигма семантеми «sonare» - у віднайденій формі симбіозу змістовного коду власне сонатності (подієвий чинник) та маневру квазі-імпровізації (лінеарний чинник), що заразом оригінально накреслюють структурносемантичну прогресію «відкритої» композиційної форми.

Наукова новизна. Її визначає здобуте переконання у тому, що творчі концепції фортепіанних композицій закарпатських композиторів періоду др. пол. ХХ ст. виявляють не лише історично необхідний намір «дорівнятися» до академічної практики компонування та опанування новітніми стильовими моделями творчості, але також цілеспрямовано вдаються до алгоритму іiї стильової спеціалізації в контексті стилетворчих ініціатив Інтенціонального періоду музичної культури - такої «вихідної інтенції, що зберігає себе упродовж ... становлення, виконує функцію смислової програми, процесуально і структурно розгорнутої та відповідним чином обумовлює щаблі розвитку культури $\mathrm{i}$ мистецтва» (О. П. Опанасюк) [7, 284].

Висновки. Приклади фортепіанної творчості закарпатських композиторів періоду др. пол. XX ст. свідчать, що для становлення і розвитку закарпатської композиторської школи вирішальним виявився дискурс на одночасне опанування академічними технологіями музичного мислення й новітніми (як інноваційними) стильовими мислеформами творчого процесу: у їх числі передовсім слід назвати технології стилізації та алюзійного способу розвитку стилю, які покладаються на певний полюс стильового притягання та свідомих стилістичних запозичень. Тобто, слід очевидних зрушень у стильовій парадигмі щодо національного дискурсу стилеутворення виявляється тісно пов'язаним із стильовими ремісценціями, оскільки суто національний дискурс стилеутворення прагне «дорівнятися» до макроіндивідуаційних процесів резонування у так званій історичній множині стильових систем.

\section{Jimepamypa}

1. Витвицький Василь. За океаном : зб. праць. Львів : Львівська організація Спілки композиторів України, Музикознавча комісія НТШ ім. Т. Шевченка, 1996. 132 с.

2. Герасимова-Персидська Н. О. Нове в музичному хронотопі кінця тисячоліття. Українське музикознавство. К., 1998. Вип. 28 (Музична україністика в контексті світової культури). С. 32-47.

3. Ингарден Роман. Исследования по эстетике / пер. с польского А. Ермилова и Б. Фёдорова. - М. : Издательство иностранной литературы, 1962. - 572 с.

4. Козаренко О. В. Від модернізму до постмодернізму (парадигма розвитку галицької музики XX ст.). Musica galiciana: kultura muzyczna Galicji w kontekście stosunków polsko-ukraińskich (od doby piastowsko-książęcej do roku 1945). Rzeszów : WSP, 2000. T. V. S. 247-252.

5. Консон Григорий. Целостный анализ в контексте научной методологии. Музыкальная академия. 2010, № 2. C. 140-150.

6. Москаленко В. Г. До визначення поняття «музичне мислення». Українське музикознавство. К. : НМАУ, 1998. Вип. 28 (Музична україністика в контексті світової культури). С. $48-53$.

7. Опанасюк О. П. Інтенціональність у просторі культури: мистецтвознавчий, культурологічний та філософський аспекти : монографія. К. : Аура Букс, 2018. 472 с.

8. Ручьевская Е. А. Функции музыкальной темы : монография. М.-Л. : Музыка, 1977. 160 с. 
9. Сюта Б. О. Дискурс у музиці й теорія дискурс-аналізу в сучасній науці. Студії мистецтвознавчі: Театр. Музика. Кіно. К. : ІМФЕ ім. М. Т. Рильського НАНУ, 2010. Чис. 1 (29). С. 35-42.

10. Ярко М. І. Художньо-стильові особливості українського музичного модерну в соціокультурному контексті «фази європеїзації». Музична україністика: сучасний вимір. К. : Ін-т мистецтвозн., фольклористики та етнології імені М. Т. Рильського НАНУ, 2011. Вип. 6 (збірник наукових статей пам'яті музикознавця, доктора мистецтвознавства М. М. Гордійчука). С. 189-198.

\title{
References
}

1. Vytvytskyi, V. (1996). Beyond the seas: article collection. Lviv: Lviv organization of National Union of Composers of Ukraine, Musicological commission of Shevchenko Scientific [in Ukrainian].

2. Herasymova-Persydska, N. O. (1998). New in the musical chronotop of the end of the millennium. Ukrains'ke muzykoznavstvo. Kyiv, issue 28 (Musical Ukrainianistics in the context of world culture), $32-47$ [in Ukrainian].

3. Ingarden, R. (1962). Issledovaniya po estetike [Aesthetics research] / translation from Polish by A. Ermilov and B. Fyodorov. Moscow [in Russian].

4. Kozarenko, O. B. (2000). From modernism to postmodernism (paradigm of the Galician music development in the XX c.). Musica galiciana: kultura muzyczna Galicji w kontekście stosunków polsko-ukraińskich (od doby piastowsko-książęcej do roku 1945). Rzeszów : WSP, Vol. V, 247-252 [in Ukrainian].

5. Konson, G. (2010). Holistic analysis in the context of scientific methodology. Muzykal'naya akademiya, 2 , 140-150 [in Russian].

6. Moskalenko, V. G. (1998). To the definition of musical thinking. Ukrains'ke muzykoznavstvo, issue 28 (Musical Ukrainianistics in the context of world culture), 48-53 [in Ukrainian].

7. Opanasiuk, O. P. (2018). Intentionality in the culture: art studies, culturological and philosophical aspects]: monograph. Kyiv : Aura Buks [in Ukrainian].

8. Ruchyevskaya, E. A. (1977) Funktsii muzykalnoy temyi : monograph. M.-L. : Music [in Russian].

9. Siuta, B. O. (2010). Discourse in music and the theory of discourse analysis in modern science. Studii mystetstvoznavchi: Teatr. Muzyka. Kino. 1 (29), 35-42 [in Ukrainian].

10. Yarko, M. I. (2011). Artistic and stylistic peculiarities of Ukrainian musical modernity in the socio-cultural context of the "Europeanization phase". Muzychna Ukrainistyka: suchasnyi vymir. Vol. 6 (collection of scientific articles in memory of a musicologist, M. M. Hordiichuk, Doctor of Art History), 189-198 [in Ukrainian].

Стаття надійшла до редакиії 06.11.2018 p.

УДК 784.1+783(092) Степурко

\author{
Василенко Олексій Артурович, \\ аспірант кафедри культурології \\ Національної музичної академії України \\ ім. П.І.Чайковського \\ ORCID ID 0000-0001-6586-5812 \\ kekssika@gmail.com
}

\section{ДІАЛОГІЧНІСТЬ ЯК ВИКОНАВСЬКА УСТАНОВКА У «MISSA MOVERE» BIKTOPA CTEПУРКA}

\begin{abstract}
Метою статті $є$ встановлення ознак діалогічності як філософської основи художнього методу у виконавському аналізі хорового твору Віктора Степурка «Missa movere». Методологія дослідження полягає в поєднанні історико-культурного, порівняльного, контекстуального методів, за допомогою яких було охарактеризовано специфіку цього твору, висвітлено історію написання, визначено композиційнодраматургічні особливості твору В.Степурка «Missa movere», їх вплив на диригентську інтерпретацію. Наукова новизна полягає у введенні поняття діалогічності, що увійшло до категорій філософії, публіцистики та літературознавства на початку XX століття, в контекст виконавського аналізу жанрових особливостей хорової творчості В.Степурка. Висновки свідчать про те, що одним з головних досягнень В.Степурка у розвитку національної хорової музики, стає збагачення традиційної жанрової палітри - новими сенсами. Діалог культур, що становить сенсовий стрижень цього твору, є важливим орієнтиром виконавської інтерпретації.
\end{abstract}

Ключові слова: меса, реквієм, діалогічність, духовна музика, виконавський аналіз, хорова партитура

Василенко Алексей Артурович, аспирант кафедры культурологии Национальной музыкальной академии Украины им.П.И.Чайковского

Диалогичность как исполнительская установка в «Missa movere» Виктора Степурко

(C) Василенко О. А., 2019 